Jurnal Ilmiah Ibnu Sina, 6(1), Maret 2021, 1-10

p-ISSN: 2502-647X; e-ISSN: 2503-1902

\title{
OPTIMASI SINTESIS DAN KARAKTERISASI SABUN CAIR DARI KEMIRI (Aleurites moluccana) DENGAN BANTUAN GELOMBANG ULTRASONIC
}

\author{
Aman Santoso*, Syafiuddin, Dedek Sukarianingsih, Sumari, Rini Retnosari \\ Jurusan Kimia, Fakultas MIPA, Universitas Negeri Malang \\ *Emai: aman.santoso.fmipa@um.ac.id
}

Artikel diterima: 04 Agustus 2020; Disetujui: 26 Februari 2021

DOI: https://doi.org/10.36387/jiis.v6i1.545

\begin{abstract}
ABSTRAK
Sabun cair sudah menjadi kebutuhan pokok, terutama terutama pada masa pandemic covid ini. Kualitas sabun dipengaruhi oleh jenis bahan baku dan basa yang digunakan. Saponifikasi minyak kemiri dengan kalium hidroksida menghasilkan sabun cair yang berpotensi sebagai anti bakteri. Gelombang ultrasonik (US) menghasilkan kavitasi yang mempercepat reaksi. Penelitian ini bertujuan: (1) Sintesis dan karakterisasi sabun cair dari minyak kemiri, (2) menentukan aktifitas antibakteri sabun cair hasil sintesis. Tahapan dalam penelitian ini adalah : (1) isolasi serta karakterisasi minyak kemiri, (2) pembuatan sabun cair dengan 3 pada berbagai konsentrasi basa dengan US (3) karakterisasi sabun cair (4) uji aktivitas antibakteri. Hasil penelitian menunjukkan sabun cair telah dapat dibuat dengan saponifikasi dengan $\mathrm{KOH}$ minyak kemiri, diperoleh sifat fisik bentuk cair kental, warna putih kekuningan, beraroma khas. Sifat kimia sabun cair memiliki massa jenis $1,10 \mathrm{~g} / \mathrm{mL}$, kadar asam lemakbebas $0,34 \%, \mathrm{pH} 8,46$, kadar alkali bebas $0,05 \%$, tegangan permukaan $4,33 \times 10^{-4} \mathrm{~N} / \mathrm{m}$, serta viskositas 1.460 cSt. Sabun cair kemiri memiliki aktivitas antibacteri dalam kategori lemah terhadap bakteri E. coli dan dalam kategori sedang terhadap bakteri S. aureus.
\end{abstract}

Kata kunci: minyak kemiri, $\mathrm{KOH}$, sabun cair, ultrasonik, antibakteri

\section{ABSTRACT}

Liquid soap has become a basic necessity, especially during the Covid pandemic. The quality of soap is influenced by the type of raw material used. Candlenut oil saponification with potassium hydroxide produces liquid soap which has the potential to be anti-bacterial. Ultrasonic waves (US) produce cavitation which speeds up the reaction. This study aims: (1) Synthesis and characterization of liquid hazelnut oil soap, (2) to determine the antibacterial activity of liquid soap. The stages in this study were: (1) isolation and characterization of hazelnut oil, (2) making liquid soap at various alkaline concentrations with US (3) characterizing liquid soap (4) testing for antibacterial activity. The results showed that liquid soap can be made by saponification with $\mathrm{KOH}$ hazelnut oil, obtained physical properties of viscous liquid form, yellowish white color, distinctive aroma. The chemical properties of liquid soap have a $\mathrm{pH}$ of 8.46 , a density of $1.10 \mathrm{~g} / \mathrm{mL}$, a free fatty acid content of $0.34 \%$, a free alkaline content of $0.05 \%$, a viscosity of $1,460 \mathrm{cSt}$ and a 
Jurnal Ilmiah Ibnu Sina, 6(1), Maret 2021, 1-10

p-ISSN: 2502-647X; e-ISSN: 2503-1902

surface tension of $4.33 \times 10^{-4} \mathrm{~N} / \mathrm{m}$. Candlenut liquid soap has antibacterial activity in the weak category against $E$. coli bacteria and in the moderate category against S. aureus bacteria.

Keywords: candlenut, $\mathrm{KOH}$, liquid soap, ultrasonic, anti-bacterial

\section{PENDAHULUAN}

Nilai ekonomis minyak nabati dapat ditingkatkan dengan mengkonversi menjadi produk baru misalnya seperti kosmetik, biodiesel dan sabun (Arlene, 2010; Jalaluddin et al., 2018). Salah satu hasil minyak nabati yang melimpah misalnya minyak kemiri yang dapat diisolasi dengan ekstraksi soxhletasi, maserasi dan pengepresan kemiri (Darmawan, 2006). Komponen utama minyak kemiri asam palmitat, asam linoleate, dan asam stearat $6,7 \%$, dimana asam asam nya dapat menghambat bakteri Staphyloccoccus aureus dengan aktivitas sebesar 19,95\% (Alodokter, 2020; Subroto et al., 2017), (Khameneh et al., 2019), (Darmawan, 2006; Benitez-Sánchez, LeónCamacho and Aparicio, 2003).

Sabun dapat bertindak sebagai agen pembersih untuk melarutkan kotoran dan juga bertindak sebagai antibakteri. Manfaat secara medis sabun dapat mereduksi total mikroorganisme penyebab penyakit seperti bacteri, virus, serta bentuk parasit lainnya, (Kumalasari et al., 2014; Widyasanti, Winaya and Rosalinda, 2019). Sabun memiliki berbagai macam bentuk misalnya berbentuk gel, bentuk padat (batang), serbuk (detergen), dan cair (George and Raymond, 2016). Sabun cair merupakan produk yang lebih banyak diminati dibandingkan sabun padat oleh masyarakat sekarang ini, karena sabun cair lebih praktis, higenis dan ekonomis (Cella and Stefani, 2018). Penggunaan ultrasonik berpotensi mempercepat reaksi pembuatan sabun cair.

Efek dari gelombang ultrasonik dapat dimanfaatkan untuk meningkatkan laju reaksi pada beberapa proses kimia (Hielscher, 2020; Mady et al., 2012). Penggunaan gelombang ultrasonik dalam reaksi dapat menurunkan energi aktifasi dan meningkatkan laju reaksi (Chen and Kalback, 1967; Naveena et al., 2015). Berdasarkan pembahasan yang telah dilakukan dan mengingat 
Jurnal Ilmiah Ibnu Sina, 6(1), Maret 2021, 1-10

p-ISSN: 2502-647X; e-ISSN: 2503-1902

tingginya kebutuhan sabun cair, maka penelitian ini bertujuan mensintesis dan mengkarakterisasi sabun cair dari minyak kemiri, serta uji aktifitas becterinya.

\section{METODE PENELITIAN}

\section{Alat serta bahan}

Peralatan yang digunakan dalam penelitian anatara lain: seperangkat alat destilasi, set ekstraksi soxhlet, Beaker Glass, Erlenmeyer, buret L, gelas arloji, spatula, kaca pengaduk,, mortar dan pestle, neraca digital merk Shimadzu, hotplate stirer, termometer, pemanas mantel, gelas ukur, $A B B E$ refractometer, viskosimeter Brookfield, dan ultrasonik merk Branson 1510 EDTH.

Bahan-bahan yang digunakan pada penelitian : Sodium hidroksida, sodium lauril sulfat, gliserin, BHT (butyl hidroksi toluen), minyak kemiri, aquades, asam citrat, phenolftalein, etanol 96\%, bacto pepton, nutrient agar, $\mathrm{HCl} \quad, \quad$ sediaan bakteri Escherichia coli dan Staphylococcus aureus.

\section{Isolasi Minyak Kemiri}

Sebanyak 1000 g kemiri direndam dalam $n$-heksana selama 24 jam. Selanjutnya disaring, ekstrak minyak yang dihasilkan dievaporasi menggunakan rotary evaporator pada suhu $\pm 35 \quad{ }^{\circ}$ C. Setelah dilakukan pemisahan pelarut (evaporasi), dikarakterisasi dan dihitung rendemennya

\section{Sintesis Sabun Cair}

Sintesis sabun cair dibuat dengan tiga komposisi variasi basa yakni 2,$5 ; 3,0$ serta $3,5 \mathrm{~g}$.

Tabel 1. Komposisi Bahan untuk Sintesis Sabun Cair

\begin{tabular}{lccc}
\hline Bahan & SKTU1 & SKTU2 & SKTU3 \\
\hline KOH $(\mathrm{g})$ & 2,5 & 3 & 3,5 \\
$\begin{array}{l}\text { Minyak } \\
\text { kemiri } \\
(\mathrm{g})\end{array}$ & 5 & 5 & 5 \\
$\begin{array}{l}\text { Gliserin } \\
(\mathrm{mL})\end{array}$ & 1 & 1 & 1 \\
$\begin{array}{l}\text { Sodium } \\
\text { lauryl }\end{array}$ & 5 & 5 & 5 \\
sulfate & & & \\
(g) & & & \\
BHT (g) & 0,2 & 0,2 & 0,2 \\
$\begin{array}{l}\text { Asam } \\
\text { Sitrat (g) }\end{array}$ & 1,5 & 1,5 & 1,5 \\
Keterangan & & & \\
\hline
\end{tabular}

Keterangan :

SKTU1: komposisi sabun dengan $\mathrm{KOH} 2,5 \mathrm{~g}$

SKTU3: komposisi sabun dengan $\mathrm{KOH} 3 \mathrm{~g}$

SKTU3: komposisi sabun dengan $\mathrm{KOH} 3,5 \mathrm{~g}$

Campuran bahan seperti pada Tabel 1 dipanaskan sambil diaduk 
Jurnal Ilmiah Ibnu Sina, 6(1), Maret 2021, 1-10

p-ISSN: 2502-647X; e-ISSN: 2503-1902

pada suhu sekitar $70^{\circ} \mathrm{C}$ dalam ultrasonic bath, selama satu jam sehingga membentuk cairan kental. Sabun yang dihasilkan dikarakterisasi untuk uji organoleptik, massa jenis, $\mathrm{pH}$, viskositas , uji kadar asam lemak bebas (ALB), tegangan permukaan.dan kadar alkali bebasnya.

\section{Karakterisasi Sabun Cair}

\section{Uji Organoleptik}

Uji organoleptik dilakukan meliputi bentuk, warna dan aroma. Hasilnya disesuaikan dengan dengan SNI sabun cair.

\section{Massa Jenis}

Sabun cair dimasukkan kedalam piknometer $25 \mathrm{~mL}$ yang telah ditimbang beratnya, selanjutnya dihitung dengan rumus perhitungan massa jenis

\section{Kadar asam lemak bebas}

Sebanyak 2,0018 gram sabun cair dimasukkan dalam Erlenmeyer, ditambah $20 \mathrm{~mL}$ alkohol 96\%, kemudian direfluks selama 30 menit. Selanjutnya didinginkan dan dititrasi dengan larutan $\mathrm{KOH} \quad 0,1 \mathrm{~N}$ untuk menentukan kadar asam lemak bebas.

\section{Kadar alkali bebas}

Sebanyak 2,5018 gram sabun cair dimasukkan dalam gelas piala, ditambah $50 \mathrm{~mL}$ alkohol 96\%, kemudian direfluks selama 30 menit. Dilakukan titrasi menggunakan $\mathrm{HCl}$ $0,1 \mathrm{~N}$, yang sampai warna ungu/merah muda hilang..

\section{Tegangan Permukaan}

Zat cair yang akan diukur tegangan permukaannya, dituangkan pada cawan dan diletakkan diatas penyangga cuplikan (yang pada posisi bila diturunkan maka cincin dapat mencapai permukaan zat cair). Penahan cuplikan dinaikkan hingga cincin Pt tercelup sedalam $0,5 \mathrm{~cm}$ terhadap permukaan. Kemudian lengan torsi diatur, sehingga lengan menunjuk angka nol pada piringan skala (cincin harus tetap tercelup 0,5 $\mathrm{cm}$ dari permukaan cairan selama pengerjaan ini). Setelah itu lengan torsi diputar perlahan-lahan hingga cincin terlepas dari permukaan cairan. Lalu, dihitung dengan rumus berikut.

Keterangan :

$$
\gamma=\frac{\emptyset}{\emptyset_{0}} \times \gamma_{0}
$$

$\gamma=$ Tegangan Permukaan Cairan

$\gamma_{0}=$ Tegangan Permukaan Air

$\varnothing=$ besar Sudut Putar Cairan

$\emptyset_{0}=$ Besar Sudut Putar Air

Pengujian Antibakteri pada Bakteri E. coli dan S. aureus 
Jurnal Ilmiah Ibnu Sina, 6(1), Maret 2021, 1-10

p-ISSN: 2502-647X; e-ISSN: 2503-1902

Uji bioaktifitas antibakteri akuades.

dilakukan dengan menggunakan metode difusi sumuran, dengan kontrol positif sodium lauryl sulfate dan minyak kemiri serta kontrol negatif akuades. Sampel uji yang digunakan adalah $1 \mathrm{mg}$ sabun cair. Starter bakteri diinokulasikan secara merata pada media yang telah disterilkan dalam cawan petri. Selanjutnya media padat steril yang telah diolesi starter dilubangi menggunakan bor gabus ditempat yang sesuai. Setelah itu lubang tersebut ditetesi kontrol positif, kontrol negatif, dan sabun cair sebanyak $20 \mu \mathrm{L}$, dilakukan inkubasi selama 24 jam pada suhu $37^{\circ} \mathrm{C}$. Luasan zona bening yang telah terbentuk di sekitar lubang diukur. Kontrol positif dengan minyak kemiri dan $S L S$ serta kontrol negatif dengan

\section{HASIL DAN PEMBAHASAN}

Isolasi Minyak Kemiri

Minyak kemiri berhasil diisolasi dengan metode maserasi sebesar 475 gram. Sisa minyak yang terdapat dalam residu hasil maserasi yang diisolasi dengan metode soxhletasi sebesar 78,2 gram dengan rendemen $55,32 \%$, Ketaren (1986) yaitu 5566\%. Karakteristik minyak kemiri hasil isolasi seperti disajikan dalam Gambar 1 dan Tabel 2.

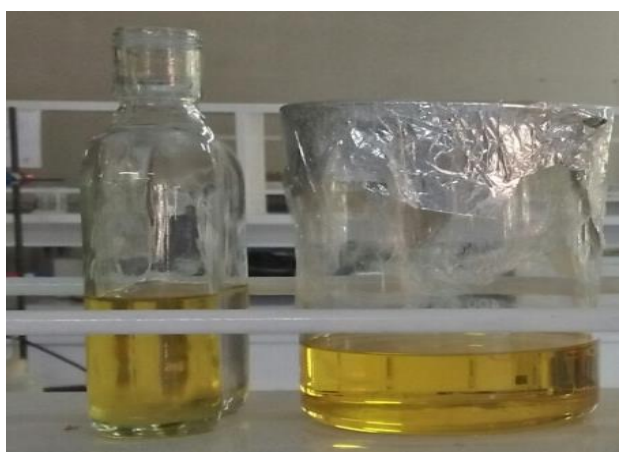

Gambar 1. Minyak Kemiri Hasil Isolasi

Tabel 2. Karakteristik Minyak Kemiri

\begin{tabular}{ccccc}
\hline \multirow{2}{*}{ Karakteristik } & \multicolumn{3}{c}{ Hasil } & \multirow{2}{*}{ SNI } \\
\cline { 2 - 4 } & 1 & 2 & Rata-rata & \\
\hline Wujud & - & - & Cair & Cair \\
Warna & - & - & Kuning & Khas \\
Densitas (g/mL) & 0,925 & 0,928 & 0,927 & $0,9240-0,9290$ \\
Bilangan asam & 6,17 & 7,27 & 6,72 & $<5$ \\
Bilangan & & & & $184-202$ \\
penyabunan mg & 203,48 & 192,18 & 197,83 & \\
$($ KOH/g Minyak) & & & & \\
\hline
\end{tabular}


Jurnal Ilmiah Ibnu Sina, 6(1), Maret 2021, 1-10

p-ISSN: 2502-647X; e-ISSN: 2503-1902

Seperti terlihat pada Tabel 2 massa jenis yang diperoleh dalam penelitian ini adalah $0,927 \mathrm{~g} / \mathrm{mL}$. Angka ini sesuai dengan standar mutu yang telah ditentukan SNI 01-44621998 yaitu sebesar $0,924-0,929 \mathrm{~g} / \mathrm{mL}$. Bilangan asam minyak kemiri diperoleh sebesar 6,72. Angka ini kurang sesuai dengan standar mutu minyak seperti dalam SNI 01-44621998 dan menunjukkan bahwa minyak tersebut memiliki kualitas yang kurang bagus. Besarnya bilangan asam disebabkan oleh lamanya penyimpanan, sehingga minyak/lemak lebih mudah terhidrolisis. Bilangan penyabunan minyak kemiri diperoleh sebesar 197,83 mg KOH/g minyak kemiri. Data tersebut memenuhi standar mutu minyak kemiri untuk bilangan penyabunan yang telah ditetapkan oleh SNI 01-4462-1998 yaitu sebesar 184-202 mg KOH/g minyak (BSN, 1998).

\section{Sintesis dan Karakterisasi Sabun Cair dari Minyak Kemiri}

Sintesis sabun cair minyak kemiri menggunakan tiga variasi basa $\mathrm{KOH}$ yaitu dengan penambahan 2,5 gram $\mathrm{KOH}$ (SKTU1), 3 gram $\mathrm{KOH}$ (SKTU2), dan 3,5 gram $\mathrm{KOH}$
(SKTU3). Sintesis sabun cair dari minyak kemiri dilakukan dalam bak ultrasonik dengan frekuensi $42 \mathrm{kHz}$, suhu $\pm 70{ }^{\circ} \mathrm{C}$ dan waktu 60 menit. Produk sabun cair hasil sintesis pada berbagai massa kalium hidroksida terlihat pada Gambar 2.

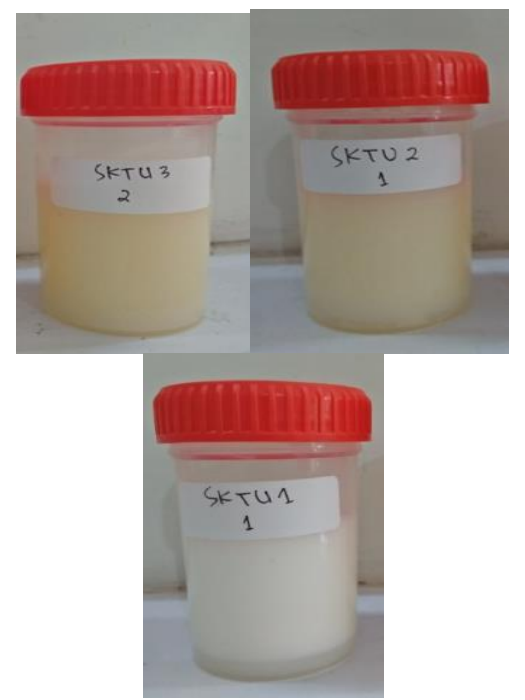

Gambar 2. Sabun cair pada berbagai komposisi $\mathrm{KOH}$

Sabun cair dari minyak kemiri hasil sintesis memiliki karakter fisik dan kimia yang berbeda untuk masingmasing variasi penambahan $\mathrm{KOH}$. Hasil karakterisasi sabun cair pada berbagai komposisi disajikan seperti dalam Tabel 3.

Seperti terlihat pada Tabel 3, uji organoleptik pada sabun cair dari minyak kemiri adalah bewujud cair warna putih hingga kekuningan dan memiliki aroma khas, sesuai dalam 
Jurnal Ilmiah Ibnu Sina, 6(1), Maret 2021, 1-10

p-ISSN: 2502-647X; e-ISSN: 2503-1902

rentangan SNI sabun cair.

Hasil pengujian alkali bebas menunjukkan bahwa semakin banyak penambahan $\mathrm{KOH}$ terhadap sintesis sabun cair, kadar alkali bebas semakin besar. (Arlene, 2010; BSN, 1998).

Salah satu karakter yang mempengaruhi keterterimaan konsumen lainnya viskositas.
Kekentalan atau viskositas yang tinggi akan mengurangi efisiensi tumbukan antar partikel di dalam sabun sehingga sediaan lebih stabil. Viskositas sabun cair pada semua produk memenuhi standar SNI 06-4085-1996 yang ada pada rentangan 500-20.000 cPs (BSN, 1996; Widyasanti et al., 2019).

Tabel 3. Karakter Sabun Cair dari Minyak Kemiri

\begin{tabular}{ccccc}
\hline Karakteristik & SKTU1 & SKTU2 & SKTU3 & SNI \\
\hline Wujud & Cair & Cair & Cair & Cair \\
Warna & Putih & $\begin{array}{c}\text { Putih } \\
\text { kekuningan }\end{array}$ & $\begin{array}{c}\text { Putih } \\
\text { kekuningan }\end{array}$ & Khas \\
Aroma & Khas SLS & Khas SLS & Khas SLS & Khas \\
pH & 8,62 & 8,46 & 13,51 & $8-11$ \\
Densitas $(\mathrm{g} / \mathrm{mL})$ & 1,09 & 1,10 & 1,11 & $1,01-1,10$ \\
FFA $(\%)$ & 0,69 & 0,34 & 0 & $<2,5$ \\
Alkali bebas $(\%)$ & 0 & 0,05 & 0,73 & $<0,1$ \\
Viskositas cPs) & 10.000 & 1.460 & 1.160 & $500-$ \\
Tegangan & & & & 20.000 \\
permukaan $(\mathrm{N} / \mathrm{m})$ & $4,33 \times 10^{-4}$ & $4,33 \times 10^{-4}$ & $4,12 \times 10^{-4}$ & - \\
\hline
\end{tabular}

Pengujian Antibakteri terhadap $S$. aureus dan E. coli

Pelaksanaan uji aktivitas antibakteri sabun cair minyak kemiri dengan memakai metode difusi agar. Aktivitas antibakteri sabun mandi cair dari minyak kemiri dapat dilihat dari terbentuknya zona hambat yang ada (Riaz et al., 2009; Yu et al., 2018). Kriteria kekuatan kekuatan daya hambat disajikan dalam Tabel 4.
Tabel 4. Kriteria daya hambat anti bacteri

\begin{tabular}{lcc}
\hline No. & Diameter & Kriteria \\
\hline 1 & $<5$ & lemah \\
2 & $5-10$ & sedang \\
3 & $10-20$ & kuat \\
4 & $>20$ & sangat kuat \\
\hline
\end{tabular}

Aktivitas Sabun Cair dari Minyak

Kemiri terhadap Bakteri $E$. coli

Diameter hambat sabun cair terhadap bakteri $E$. coli dapat dilihat pada Gambar 3. 


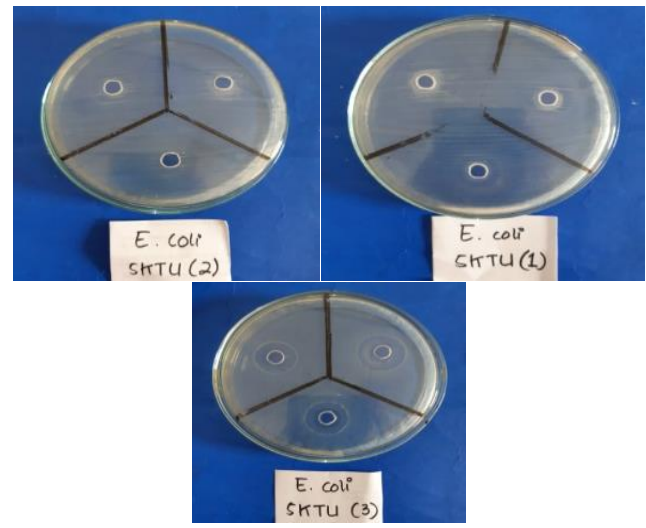

Gambar 3. Diameter Hambat Sabun Cair terhadap Bakteri E. coli

Perhitungan zona hambat dalam uji antibakteri sabun cair terhadap bakteri E. coli disajikan padaTabel 5.

Hasil menunjukkan bahwa produk sabun cair hasil sintesis dengan penambahan 2,5 g $\mathrm{KOH}$ (SKTU1) dan penambahan 3,0 g KOH (SKTU2) memiliki daya hambat dengan kategori lemah. Produk SKTU 3 dengan penambahan 3,5 g $\mathrm{KOH}$ memiliki daya hambat dengan kategori kuat, hal ini karena $\mathrm{pH}$ pada sabun tersebut adalah 13,5, sedangkan pertumbuhan bakteri E. coli maksimum pada $\mathrm{pH}$ 9, oleh karena itu daya hambat terhadap bakteri E. coli juga semakin kuat (Kaseng et al., 2016; Kumalasari et al., 2014).

Tabel 5. Data Hasil Uji Antibakteri Sabun Cair terhadap Bakteri E. coli

\begin{tabular}{|c|c|c|c|c|c|}
\hline \multirow[t]{2}{*}{ Sampel } & \multicolumn{3}{|c|}{ Zona Bening (mm) } & \multirow{2}{*}{$\begin{array}{c}\text { Rata- } \\
\text { rata }\end{array}$} & \multirow[t]{2}{*}{ Kategori } \\
\hline & 1 & 2 & 3 & & \\
\hline SKTU1 & 1,20 & 0,30 & 1,10 & 0,87 & Lemah \\
\hline SKTU2 & 1,10 & 1,75 & 1,60 & 1,48 & Lemah \\
\hline SKTU3 & 11,85 & 11,15 & 13,15 & 12,05 & Kuat \\
\hline Kontrol + 1 & 1,25 & 0,35 & 1,35 & 0,98 & Lemah \\
\hline Kontrol +2 & 0 & 0 & 0 & 0 & - \\
\hline Kontrol - & 0 & 0 & 0 & 0 & - \\
\hline
\end{tabular}

Keterangan :

SKTU1 : penambahan $\mathrm{KOH} 2,5 \mathrm{~g}$

SKTU2 : penambahan $\mathrm{KOH} \mathrm{3,0} \mathrm{g}$

SKTU3 : penambahan $\mathrm{KOH} \mathrm{3,5 \textrm {g }}$

\section{KESIMPULAN}

Sabun cair keniri dapat dibuat dengan reaksi saponifikasi minyak kemiri dengan basa $\mathrm{KOH}$, diperoleh sifat fisik sabun bentuk cair kental, warna putih kekuningan, beraroma
Kontrol $+1 \quad$ : Minyak kemiri Kontrol +2 : sodium lauryl sulfate Kontrol - : : Aquades

khas. Sifat kimia sabun cair memiliki massa jenis $1,10 \mathrm{~g} / \mathrm{mL}$, pH 8,46, kadar asam lemak bebas 0,34\%, dan tegangan permukaan $4,33 \times 10-4 \mathrm{~N} / \mathrm{m}$. , viskositas 1.460 cSt Sabun cair dari minyak kemiri menunjukkan aktivitas 
Jurnal Ilmiah Ibnu Sina, 6(1), Maret 2021, 1-10

p-ISSN: 2502-647X; e-ISSN: 2503-1902

terhadap bakteri Escherichia coli dengan kategori lemah untuk produk sabun SKTU1 dan SKTU2, serta kategori sedang kuat untuk produk SKTU3. Sedangkan aktivitas antibakteri terhadap bakteri Staphylococcus aureus dengan termasuk dalam kategori sedang pada semua produk sabun cair hasil sintesis dari minyak kemiri.

\section{UCAPAN TERIMA KASIH}

Terima kasih diucapkan kepada LP2M Universitas Negeri Malang telah mendanai seluruh penelitian ini melalui dana PNBP UM.

\section{DAFTAR PUSTAKA}

Arlene, A., 2010. Pembuatan Sabun dari Minyak Kemiri. Res. Rep.Eng. Sci. 1.

BSN, 1998. Minyak Kemiri SNI 014462-1998. Badan Standardisasi Nasional, Jakarta.

BSN, 1996. Sabun Mandi Cair SNI 064085-1996. Badan Standardisasi Nasional, Jakarta.

Cella, R., Stefani, H.A., 2018. Ultrasonic Reactions, in: Green Techniques for Organic Synthesis and Medicinal Chemistry. John Wiley \& Sons, Ltd, pp. 343-371. https://doi.org/10.1002/9781119 288152.ch14
Chen, J.W., Kalback, W.M., 1967. Effect of Ultrasound on Chemical Reaction Rate. Ind. Eng. Chem. Fundam. 6, 175178ttps://doi. org/10.1021/i160022a003.

Darmawan, S., 2006. Pembuatan Minyak Kemiri Dan Pemurniannya Dengan Arang Aktif Dan Bentonit. J. Penelit. Has. Hutan 24, 413-423. https://doi.org/10.20886/jphh.20 06.24.5.413-423

Davis, W.W., McGuire, J.M., Parke, T.V., 1949. Some new procedures and instruments useful for microbiological antibiotic testing by diffusion methods. I. A new zone reader. J. Am. Pharm. Assoc. 38, 459462. https://doi.org /10.1002/jps.3030380813

Desiyanto, F.A., Djannah, S.N., 2013. Efektivitas Mencuci Tangan Menggunakan Cairan Pembersih Tangan Antiseptik (Hand Sanitizer) Terhadap Jumlah Angka KumaN. Kes Mas J. Fak. Kesehat. Masy. 7, 75-82. https://doi.org/10.12928/kesmas .v7i2.1041

George, E.D., Raymond, D.J., 2016. 3 - Formulation of Traditional Soap Cleansing Systems, in: Spitz, L. (Ed.), Soap Manufacturing Technology (Second Edition). AOCS Press, pp. 55-72. https://doi.org/10.1016/B978-163067-065-8.50003-7

Hernani, Bunasor, T.K., Fitriati, 2010. Formula Sabun Transparan Antijamur dengan Bahan Aktif Ekstrak Lengkuas (Alpinia 
Jurnal Ilmiah Ibnu Sina, 6(1), Maret 2021, 1-10

p-ISSN: 2502-647X; e-ISSN: 2503-1902

galanga L.Swartz.). Bul. Penelit. Tanam. Rempah Dan Obat 21, 192-205.

Hielscher, 2020. Ultrasonic Dissolving of Solids in Liquid [WWW Document]. Hielscher. URL

https://www.hielscher.com/ultra sonic-dissolving-of-solids-inliquids.htm (accessed 6.23.20).

Jalaluddin, Aji, A., Nuriani, S., 2018. Pemanfaatan Minyak Sereh (Clymbopogon nardus L.) sebagai Antioksidan pada Sabun Mandi Padat. J. Teknol. Kim. Unimal 17, 56-60.

Kaseng, E.S., Muhlishah, N., Irawan, S., 2016. Uji Daya Hambat terhadap Pertumbuhan Bakteri Uji Staphylococcus aureus dan Escherichia coli Ekstrak Etanol Daun Mangrove Rhizophora mucronata dan Efek Antidiabetiknya pada Mencit yang Diinduksi Aloksan. Bionature 17, 1-6.

Ketaren, S., 1986. Pengantar Teknologi Minyak dan Lemak Pangan. UI Press, Jakarta.

Khameneh, B., Iranshahy, M., Soheili, V., Fazly Bazzaz, B.S., 2019. Review on plant antimicrobials: a mechanistic viewpoint. Antimicrob. Resist. Infect. Control 8, 118-118. https://doi.org/10.1186/s13756019-0559-6

Kumalasari, D., Fasya, A.G., Adi, T.K., Maunatin, A., 2014. Uji Aktivitas Antibakteri Asam Lemak Hasil Hidrolisis Minyak Mikroalga Chlorella sp. Alchemy J. Chem. 3, 163-172.
Mady, M.F., El-Kateb, A.A., Zeid, I.F., Jørgensen, K.B., 2012. Comparative Studies on Conventional and UltrasoundAssisted Synthesis of Novel Homoallylic Alcohol Derivatives Linked to Sulfonyl Dibenzene Moiety in Aqueous Media. J. Chem. 2013, 364036.

Riaz, S., Ahmad, A., Hasnain, S., 2009. Antibacterial Activity of Soaps Against Daily Encountered Bacteria. Afr. J. Biotechnol. 8, 1431-1436.

Subroto, E., Widjojokusumo, E., Veriansyah, B., Tjandrawinata, R.R., 2017. Supercritical CO(2) extraction of candlenut oil: process optimization using Taguchi orthogonal array and physicochemical properties of the oil. J. Food Sci. Technol. 54, 1286-1292.

https://doi.org/10.1007/s13197017-2542-7

Widyasanti, A., Rahayu, A.Y., Zein, S., 2017. Pembuatan Sabun Cair Berbasis Virgin Coconut Oil (VCO) Dengan Penambahan Minyak Melati (Jasminum sambac) Sebagai Essential Oil. Teknotan J. Ind. Teknol. Pertan. 11, 1-10. https://doi.org/10.24198/jt.vol1 $\ln 2.102$

Yu, J.J., Manus, M.B., Mueller, O., Windsor, S.C., Horvath, J.E., Nunn, C.L., 2018. Antibacterial soap use impacts skin microbial communities in rural Madagascar. Plos ONE 13, e0199899.

https://doi.org/10.1371/journal. pone.0199899 